\title{
Ruthenium vs. Osmium Complexes as Catalysts for Atom Transfer Radical Addition Reactions
}

\author{
Mariano A. Fernández-Zúmel, ${ }^{\text {[a] }}$ Gregor Kiefer, ${ }^{\text {[a] }}$ Katrin Thommes, ${ }^{\text {[a] }}$ Rosario Scopelliti, ${ }^{\text {[a] }}$ \\ and Kay Severin**a]
}

Keywords: ATRA / ATRC / Osmium / Radical reactions / Ruthenium

The catalytic activity of $\left[\mathrm{Cp}{ }^{*} \mathrm{OsBr}_{2}\left(\mathrm{PPh}_{3}\right)\right]$ in conjunction with $\mathrm{Mg}$ has been evaluated for atom transfer radical addition (ATRA) and cyclization (ATRC) reactions. The Os complex enabled these reactions to be performed with similar efficiency as that of the analogous $\mathrm{Ru}$ complex $\left[\mathrm{Cp}^{*} \mathrm{RuCl}_{2}\right.$ $\left.\left(\mathrm{PPh}_{3}\right)\right]$. The olefin complex $\left[\mathrm{Cp}{ }^{*} \mathrm{OsBr}\left(\mathrm{H}_{2} \mathrm{C}=\mathrm{CHPh}\right)\left(\mathrm{PPh}_{3}\right)\right]$ was obtained by reduction of $\left[\mathrm{Cp}^{*} \mathrm{OsBr}_{2}\left(\mathrm{PPh}_{3}\right)\right]$ with $\mathrm{Mg}$ in the presence of an excess of styrene, whereas an analogous $\mathrm{Ru}$ complex was not observed. Kinetic investigations suggest that olefin complexes of Os can form under catalytic conditions.

\section{Introduction}

Halogenated compounds can be coupled to olefins by an atom transfer radical addition mechanism. Pioneering studies in this area were performed by Kharasch and his group in the $1940 \mathrm{~s},{ }^{[1]}$ and reactions of this type are commonly referred to as "Kharasch reactions". ${ }^{[2]}$ Modern, transition-metal-catalyzed versions of this reaction have found numerous applications in organic synthesis. ${ }^{[2,3]}$ Copper $^{[4]}$ and ruthenium complexes ${ }^{[5,6]}$ typically show the best catalytic performance for ATRA reactions. One of the most active catalysts described so far is the half-sandwich complex $\left[\mathrm{Cp} * \mathrm{RuCl}_{2}\left(\mathrm{PPh}_{3}\right)\right]$ (1), which is used in conjunction with either AIBN or Mg. ${ }^{[6]}$ This catalytic system enables turnover numbers of 1000 or above to be obtained for a number of substrates. Furthermore, it has been successfully applied to atom transfer radical cyclization (ATRC) reactions, which are particularly interesting from a synthetic point of view. ${ }^{[6 a]}$

The metal-catalyzed atom transfer radical polymerization (ATRP) of olefins is mechanistically closely related to ATRA reactions. ${ }^{\left[{ }^{[b]}\right]}$ For the former reaction, it was reported that the $\mathrm{Os}^{\mathrm{II}}$ complex $\left[\mathrm{Cp} * \mathrm{OsBr}\left(\mathrm{P} i \mathrm{Pr}_{3}\right)\right]$ is a more active catalyst than its $\mathrm{Ru}$ analogue $\left[\mathrm{Cp} * \mathrm{RuCl}\left(\mathrm{P}_{i} \operatorname{Pr}_{3}\right)\right]^{[7]}$ This finding suggested that Os complexes could also be beneficial for ATRA and ATRC reactions. Below we report the results of a study in which we have compared the catalytic activity of the complex $\left[\mathrm{Cp} * \mathrm{RuCl}_{2}\left(\mathrm{PPh}_{3}\right)\right](\mathbf{1})$ with that of its Os analogue $\left[\mathrm{Cp} * \mathrm{OsBr}_{2}\left(\mathrm{PPh}_{3}\right)\right]$ (2). Furthermore, we demonstrate that olefin complexes are readily formed in the

[a] Institut des Sciences et Ingénierie Chimiques, École

Polytechnique Fédérale de Lausanne (EPFL)

1015 Lausanne, Suisse

Fax: +41-21-693-9305

E-mail: kay.severin@epfl.ch case of Os, whereas the analogous Ru complexes are significantly less stable. The implication of this finding for the mechanism of the reaction is discussed.

\section{Results and Discussion}

First, we have evaluated the catalytic performance of the complexes [Cp* $\left.\mathrm{RuCl}_{2}\left(\mathrm{PPh}_{3}\right)\right]$ (1) and [Cp* $\left.\mathrm{OsBr}_{2}\left(\mathrm{PPh}_{3}\right)\right]$ (2) for different intermolecular ATRA reactions. Complex $\mathbf{2}$ is not a perfect analogue of $\mathbf{1}$, because - apart from the metal - the halide coligand has also been changed from chloride to bromide. The synthetic chemistry of organometallic Os-Br complexes is much more developed than the chemistry of $\mathrm{Os}-\mathrm{Cl}$ complexes (the reduction of $\mathrm{OsO}_{4}$ is more facile with $\mathrm{HBr}$ than with $\mathrm{HCl}$ ).

The halogenated compounds used in our study were ethyl trichloroacetate, ethyl dichloroacetate, and chloroform, and the olefinic reaction partner was styrene. The reactions were performed with substrate concentrations of [styrene $]=[\mathrm{R}-\mathrm{Cl}]=500 \mathrm{~mm}$ in neat toluene with catalyst concentrations of 0.1 and $0.02 \mathrm{~mol}-\%$. All reactions were carried out in the presence of an excess of $\mathrm{Mg}$ powder. It should be noted that these conditions are not necessarily the optimum conditions for these reactions (faster conversions can be achieved with higher substrate concentrations), ${ }^{[6 a]}$ but the goal of this study was to evaluate the relative performance of the $\mathrm{Ru}$ and the Os catalyst. The results of the reactions are summarized in Table 1.

For the addition of ethyl dichloroacetate to styrene at room temp. we found that reactions with the Ru complex $\mathbf{1}$ were faster than with the Os complex 2: after $24 \mathrm{~h}$, we observed a full conversion of styrene in the case of complex 1 , whereas a conversion of only $57 \%$ was recorded for reactions with complex 2 (Table 1, Entries 1 and 2). At $60^{\circ} \mathrm{C}$, 
Table 1. ATRA reactions of chlorinated compounds to styrene catalyzed by complex $\mathbf{1}$ or $\mathbf{2}$ in the presence of $\mathbf{M g}$. ${ }^{[a]}$

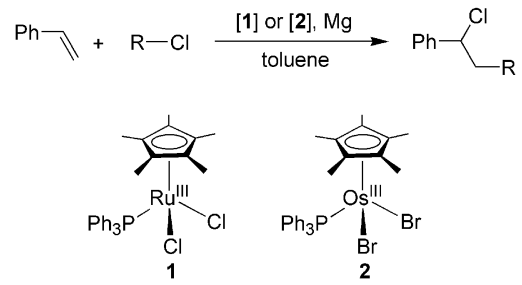

\begin{tabular}{cccccc}
\hline Entry & Cat. & $\mathrm{RCl}$ & Temp. $\left[{ }^{\circ} \mathrm{C}\right]$ & {$[\mathrm{RCl}] /[\mathrm{Cat}]$} & $\begin{array}{c}\text { Yield (Conv.) } \\
{[\%]}\end{array}$ \\
\hline 1 & $\mathbf{1}$ & $\mathrm{CCl}_{2} \mathrm{HCO}_{2} \mathrm{Et}$ & r.t. & $1000: 1$ & $84(>99)$ \\
2 & $\mathbf{2}$ & $\mathrm{CCl}_{2} \mathrm{HCO}_{2} \mathrm{Et}$ & r.t. & $1000: 1$ & $42(57)$ \\
3 & $\mathbf{1}$ & $\mathrm{CCl}_{2} \mathrm{HCO}_{2} \mathrm{Et}$ & 60 & $1000: 1$ & $84(>99)$ \\
4 & $\mathbf{2}$ & $\mathrm{CCl}_{2} \mathrm{HCO}_{2} \mathrm{Et}$ & 60 & $1000: 1$ & $84(>99)$ \\
5 & $\mathbf{1}$ & $\mathrm{CCl}_{2} \mathrm{HCO}_{2} \mathrm{Et}$ & 60 & $5000: 1$ & $14(31)$ \\
6 & $\mathbf{2}$ & $\mathrm{CCl}_{2} \mathrm{HCO}_{2} \mathrm{Et}$ & 60 & $5000: 1$ & $16(39)$ \\
7 & $\mathbf{1}$ & $\mathrm{CCl}_{3} \mathrm{CO}_{2} \mathrm{Et}$ & 60 & $1000: 1$ & $55(83)$ \\
8 & $\mathbf{2}$ & $\mathrm{CCl}_{3} \mathrm{CO}_{2} \mathrm{Et}$ & 60 & $1000: 1$ & $24(45)$ \\
9 & $\mathbf{1}$ & $\mathrm{CCl}_{3} \mathrm{CO}_{2} \mathrm{Et}$ & 60 & $5000: 1$ & $17(31)$ \\
10 & $\mathbf{2}$ & $\mathrm{CCl}_{3} \mathrm{CO}_{2} \mathrm{Et}$ & 60 & $5000: 1$ & $3(14)$ \\
11 & $\mathbf{1}$ & $\mathrm{CHCl}_{3}$ & 60 & $1000: 1$ & $28(47)$ \\
12 & $\mathbf{2}$ & $\mathrm{CHCl}_{3}$ & 60 & $1000: 1$ & $31(47)$ \\
\hline
\end{tabular}

[a] Reaction conditions: $[\mathrm{RCl}]=500 \mathrm{~mm}$; $[$ styrene $]=500 \mathrm{~mm} ;[\mathrm{Ru} /$ Os] $=0.50$ or $0.10 \mathrm{~mm}(0.1$ or $0.02 \mathrm{~mol}-\%),[\mathrm{Mg}]=100 \mathrm{mg}$ $(4.1 \mathrm{mmol})$, toluene, reaction time $24 \mathrm{~h}$. The data represent averaged values of two independent experiments. Yields and styrene conversions were determined by GC using mesitylene as the internal standard.

however, the differences in reactivity were much less pronounced, and comparable yields and conversions were obtained for reactions with 0.1 and $0.02 \mathrm{~mol}-\%$ of catalyst (Table 1, Entries 3-6). Apparently, the Os complex 2 benefits more from the enhanced reaction temperature. A possible explanation is that the reduction of the $\mathrm{Os}^{\mathrm{III}}$ precursor 2 to a catalytically active $\mathrm{Os}^{\mathrm{II}}$ species by $\mathrm{Mg}$ is relatively slow at room temp. This assumption is substantiated by the following observation: when a toluene solution of the $\mathrm{Ru}^{\mathrm{III}}$ complex $\mathbf{1}$ is added to a flask containing $\mathrm{Mg}$, a rapid color change from orange to yellow is observed at room temp. within minutes. In the case of the Os ${ }^{\mathrm{III}}$ complex $\mathbf{2}$, however, a change in color proceeds slowly within the first hour.

For the reaction of ethyl trichloroacetate with styrene, we found that the Ru complex 1 gave superior results, even at $60{ }^{\circ} \mathrm{C}$ (Table 1, Entries 7-10). However, the differences in reactivity were not very pronounced. Comparable yields and conversions were observed for reactions with chloroform as the substrate (Table 1, Entries 11 and 12). For all reactions investigated, the yields were lower than the conversions. This is likely to be a result of the formation of oligomers, a common problem in ATRA reactions. ${ }^{[4,5]}$

Next, we tested the performance of the catalysts $\mathbf{1}$ and $\mathbf{2}$ in atom transfer radical cyclization (ATRC) reactions. We used two trichloroethyl ethers and three dichloroacetamides as representative substrates. The cyclizations were performed at $60{ }^{\circ} \mathrm{C}$ with $1.0 \mathrm{~mol}-\%$ of the complexes $\mathbf{1}$ or $\mathbf{2}$ in the presence of $\mathrm{Mg}$. The results are summarized in Table 2. In most cases the Ru complex $\mathbf{1}$ gave better results in terms of yield. On the other hand, the diastereoselectivity was higher for the Os-catalyzed reactions, in particular for the substrate 1-(2,2,2-trichloroethoxy)-3-phenylprop-2-ene (Entry 2). It should be noted, however, that the stereoselectivity was found to change during the course of the reaction. When ATRC reactions with 1-(2,2,2-trichloroethoxy)-3phenylprop-2-ene were examined after $40 \mathrm{~min}$, both the Ruand the Os-catalyzed reactions showed a diastereoselectivity of 19:1 (the yields at that point were $61 \%$ and $20 \%$, respectively). These results suggest that epimerization processes are occurring, which are more pronounced for reactions with the "faster" Ru catalyst.

Table 2 . ATRC reactions catalyzed by complex $\mathbf{1}$ or $\mathbf{2}$ in the presence of Mg. ${ }^{[\mathrm{a}]}$

\begin{tabular}{lllcc}
\hline Entry & Yield (Conv.) \\
{$[\%]$}
\end{tabular}

[a] Reaction conditions: [substrate] $=100 \mathrm{~mm}$; $[\mathrm{Ru} / \mathrm{Os}]=1.0 \mathrm{mM}$ $(1.0 \mathrm{~mol}-\%),[\mathrm{Mg}]=100 \mathrm{mg}(4.1 \mathrm{mmol}),\left[\mathrm{D}_{8}\right]$ toluene, $60{ }^{\circ} \mathrm{C}$, reaction time: $24 \mathrm{~h}$. Yields and conversions were determined by NMR spectroscopy using mesitylene as the internal standard. [b] 2.5 mol$\%$ of catalyst was used. [c] Diastereoselectivity.

For ATRA reactions with the catalyst precursor $\left[\mathrm{Cp} * \mathrm{RuCl}_{2}\left(\mathrm{PPh}_{3}\right)\right](\mathbf{1})$ it is assumed that the reaction starts by $\mathrm{Mg}$-induced reduction to give an $\mathrm{Ru}^{\mathrm{II}}$ complex that can reversibly abstract a halogen atom from the substrate ${ }^{[8]} \mathrm{A}$ likely candidate for the active $\mathrm{Ru}^{\mathrm{II}}$ catalyst is the $16 \mathrm{e}^{-}$complex $\left[\mathrm{Cp} * \mathrm{RuCl}\left(\mathrm{PPh}_{3}\right)\right]$, but attempts to prepare this complex on a preparative scale have failed. ${ }^{[9]}$ However, it was possible to stabilize a structurally related complex by using a sterically very demanding cyclopentadienyl ligand. ${ }^{[10]}$ In the case of Os, the synthesis and the structure of the $16 \mathrm{e}$ complex $\left[\mathrm{Cp}{ }^{*} \mathrm{OsBr}\left(\mathrm{P} i P r_{3}\right)\right]$ has been reported, ${ }^{[1]}$ but, to the best of our knowledge, an analogous $\mathrm{PPh}_{3}$ complex is not known. We wanted to explore the Mg-induced reduction of complex 2 in more detail. Thus, a $\left[\mathrm{D}_{8}\right]$ toluene suspension of $2(0.025 \mathrm{mmol}$ in $1 \mathrm{~mL}$ of solvent) was mixed with an excess of Mg. After $24 \mathrm{~h}$, the $\mathrm{Mg}$ was filtered off, and the solution was investigated by NMR spectroscopy. The major 
diamagnetic species in solution (36\% yield, as determined with the internal standard mesitylene) was found to be the known complex $\left[\mathrm{Cp} * \mathrm{OsBr}\left(\mathrm{PPh}_{3}\right)_{2}\right]$ (3) (Scheme 1). ${ }^{[12]}$

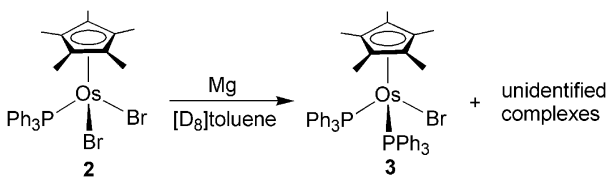

Scheme 1. Reduction of complex 2 by $\mathrm{Mg}$.

The reduction of complex 2 with $\mathrm{Mg}$ apparently induced a ligand transfer of $\mathrm{PPh}_{3}$. We have not tried to optimize this synthetic procedure since complex $\mathbf{3}$ is more conveniently obtained by reaction of $\left[\mathrm{Cp}^{*} \mathrm{OsBr}_{2}\right]_{2}$ with $\mathrm{PPh}_{3} \cdot{ }^{[12]} \mathrm{How}-$ ever, we have performed a single-crystal X-ray analysis of $\mathbf{3}$ (Figure 1). For comparison, we have also examined the solid-state structure of the precursor 2 (Figure 2).

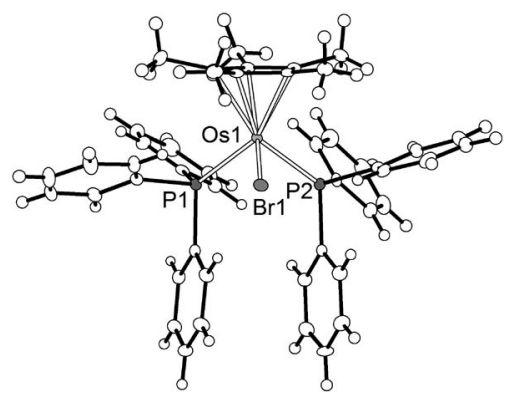

Figure 1. Molecular structure of complex 3 with ellipsoids at the $50 \%$ probability level. Only one of the two independent molecules

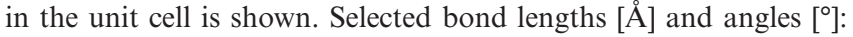
Os1-Br1 2.5934(4), Os1-P1 2.3370(9), Os1-P2 2.3313(9); P2-Os1P1 96.51(3), P2-Os1-Br1 88.61(2), P1-Os1-Br1 93.98(2).

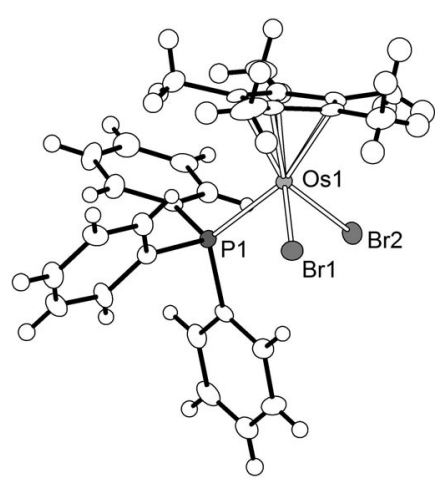

Figure 2. Molecular structure of complex 2 with ellipsoids at the $50 \%$ probability level. Selected bond lengths $[\AA]$ and angles $\left[^{\circ}\right]$ : Os1-Br1 2.5110(9), Os1-Br2 2.4955(8), Os1-P1 2.3379(1); P1-Os1Br1 88.49(5), P1-Os1-Br2 88.50(5), Br2-Os1-Br1 97.81(3).

Both complexes show the expected three-legged pianostool geometry. The Os- $\mathrm{Br}$ and Os-P bond lengths observed for 3 (Figure 1) are very similar to those found for the analogous complex $\left[\mathrm{CpOsBr}\left(\mathrm{PPh}_{3}\right)_{2}\right]\left(\mathrm{Cp}=\eta^{5}\right.$-cyclopentadienyl). ${ }^{[13]}$ The Os-Br bond lengths $[2.5110(9)$ and $2.4955(8) \AA]$ of the Os ${ }^{\mathrm{III}}$ complex 2 are shorter than that found for the Os ${ }^{\mathrm{II}}$ complex 3 [2.5934(4) $\AA$ ]. A similar shortening has been observed for the analogous $\mathrm{Ru}$ complexes $\left[\mathrm{Cp}^{*} \mathrm{RuCl}_{2}\left(\mathrm{PPh}_{3}\right)\right][\mathrm{Ru}-\mathrm{Cl} 2.4042(5) \text { and } 2.3775(5) \AA]^{[6 \mathrm{a}]}$ and $\left[\mathrm{Cp} * \mathrm{RuCl}\left(\mathrm{PPh}_{3}\right)_{2}\right][\mathrm{Ru}-\mathrm{Cl} 2.4583(6) \AA] . .^{[14]}$

We have also investigated the reduction of the complexes 1 and $\mathbf{2}$ with $\mathrm{Mg}$ in the presence of an excess of styrene (Scheme 2). This experiment was performed to evaluate the possibility that the hypothetical intermediates $\left[\mathrm{Cp} * \mathrm{MX}\left(\mathrm{PPh}_{3}\right)\right]$ are stabilized by coordination to the olefinic substrate. As before, the reactions were performed in deuterated toluene to allow in situ NMR analyses. For reactions with the Os complex 2 , we observed the formation of a new complex 4 with a ${ }^{31} \mathrm{P}$ NMR signal at $\delta=7.4 \mathrm{ppm}$. In the ${ }^{1} \mathrm{H}$ NMR spectrum, this complex showed three welldefined signals at $\delta=5.71(\mathrm{dd}), 2.91$ (ddd), and 2.47 (ddd) $\mathrm{ppm}$, which suggests the presence of coordinated styrene (the signals of "free" styrene can be observed at $\delta=6.82$, 5.86 , and $5.35 \mathrm{ppm})$. The description of $\mathbf{4}$ as an olefin complex with the formula $\left[\mathrm{Cp} * \mathrm{OsBr}\left(\mathrm{H}_{2} \mathrm{C}=\mathrm{CHPh}\right)\left(\mathrm{PPh}_{3}\right)\right]$ was also supported by the ${ }^{13} \mathrm{C}$ NMR spectroscopic data. For reactions with the Ru complex $\mathbf{1}$ we did not find evidence for the formation of a diamagnetic styrene complex (the ${ }^{1} \mathrm{H}$ NMR spectrum showed no signals between $\delta=2$ and $3 \mathrm{ppm})$. It is interesting to note that olefin complexes of the formula $\left[\mathrm{Cp} * \mathrm{RuCl}\left(\mathrm{H}_{2} \mathrm{C}=\mathrm{CHR}\right)\left(\mathrm{PPh}_{3}\right)\right]\left(\mathrm{R}=\mathrm{CN}, \mathrm{COCH}_{3}\right)$ have been prepared by reaction of $\left[\mathrm{Cp} * \mathrm{RuCl}\left(\mathrm{PPh}_{3}\right)_{2}\right]$ with the respective olefin in thf. ${ }^{[15]}$ We have attempted a similar reaction with styrene: complex $\left[\mathrm{Cp} * \mathrm{RuCl}\left(\mathrm{PPh}_{3}\right)_{2}\right]$ $(0.020 \mathrm{~mm})$ was mixed with styrene $(0.050 \mathrm{mM})$ in $\left[\mathrm{D}_{8}\right]$ thf, and an ${ }^{1} \mathrm{H}$ NMR spectrum was recorded after $4 \mathrm{~h}$. As before, we did not observe signals corresponding to an olefin complex. These results suggest that the hypothetical styrene complex $\left[\mathrm{Cp} * \mathrm{RuCl}\left(\mathrm{H}_{2} \mathrm{C}=\mathrm{CHPh}\right)\left(\mathrm{PPh}_{3}\right)\right]$ is significantly less stable than complexes with electron-deficient olefins such as acrylonitrile or 3-buten-2-one, a finding that is in line with what has been observed for other late-transition-metal complexes. ${ }^{[16]}$

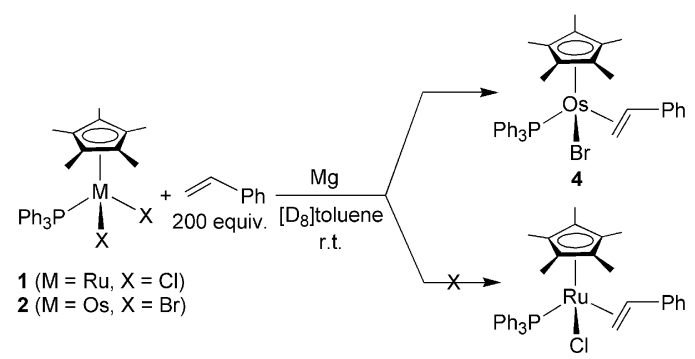

Scheme 2. Reduction of the complexes $\mathbf{1}$ and $\mathbf{2}$ by $\mathrm{Mg}$ in the presence of an excess of styrene.

The facile formation of the styrene complex $\left[\mathrm{Cp} * \mathrm{OsBr}\left(\mathrm{H}_{2} \mathrm{C}=\mathrm{CHPh}\right)\left(\mathrm{PPh}_{3}\right)\right]$ (4) has potential implications for the mechanism of Os-catalyzed ATRA reactions since olefin complexes are possible intermediates, which could inhibit the reaction. ${ }^{[17]}$ To investigate this issue in more detail, we have performed a kinetic study of the Oscatalyzed ATRA reaction of ethyl trichloroacetate with styrene. The reactions were performed with a fixed concentra- 
tion of $\left[\mathrm{Cl}_{3} \mathrm{CCO}_{2} \mathrm{Et}\right]=100 \mathrm{~mm}$ and $[2]=0.50 \mathrm{~mm}$ in the presence of $\mathrm{Mg}$ powder. The styrene concentrations were varied from $12.5 \mathrm{~mm}$ to $3.2 \mathrm{M}$, and the initial rate of the reaction was calculated from the yields obtained at nine different times within the first $25 \mathrm{~min}$. For comparison, we have performed reactions with the Ru complex $\mathbf{1}$ under otherwise identical conditions. The results are summarized in Figure 3.

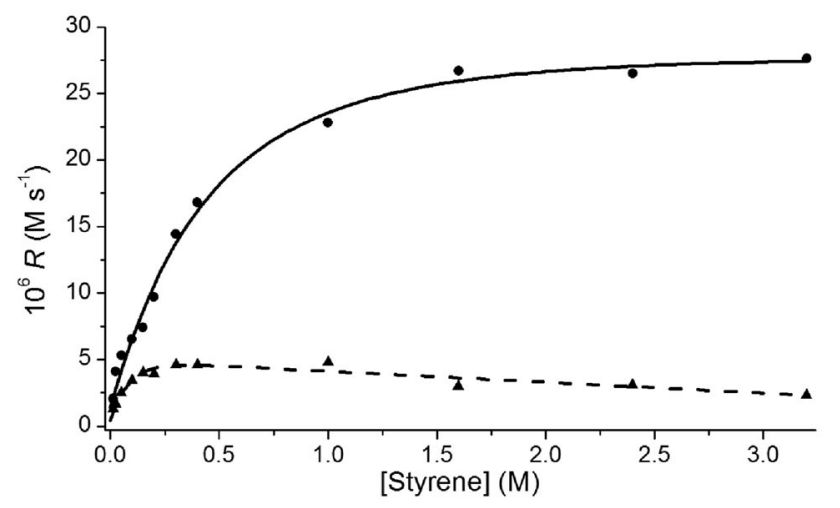

Figure 3. Observed initial reaction rates vs. initial styrene concentrations for the ATRA of ethyl trichloroacetate to styrene catalyzed by the $\mathrm{Ru}^{\mathrm{III}}$ complex $\mathbf{1}$ (dots) or by the Os ${ }^{\mathrm{III}}$ complex $\mathbf{2}$ (triangles) in the presence of $\mathrm{Mg}$. Reaction conditions: [ethyl trichloroacetate] $=100 \mathrm{~mm} ;[\mathrm{Ru} / \mathrm{Os}]=0.50 \mathrm{~mm},[\mathrm{Mg}]=100 \mathrm{mg}$, toluene, $60^{\circ} \mathrm{C}$. Yields were determined by GC using mesitylene as the internal standard.

For reactions with the Ru catalyst $\mathbf{1}$ one observes a nearly linear correlation between the initial reaction rate and the styrene concentration for [styrene] $\leq 200 \mathrm{~mm}$. This result is in line with what we observed previously for kinetic studies carried out at $35^{\circ} \mathrm{C} .{ }^{[8]}$ At higher styrene concentrations, however, the reaction rates level off with saturation occurring at [styrene] $\approx 2 \mathrm{M}$. Such a saturation is expected because the high styrene/ $\mathrm{Cl}_{3} \mathrm{CCO}_{2} \mathrm{Et}$ ratio favors oligomeric side products. ${ }^{[18]}$ Reactions with the Os complex 2 were slower than those with the Ru complex 1. Importantly, the reaction rates started to level off at much lower styrene concentrations, and concentrations of above $1 \mathrm{~m}$ led to a decrease in the rate.

In addition, we have investigated the catalytic activity of the isolated styrene complex 4, using the addition of ethyl dichloroacetate to styrene ([styrene] $=500 \mathrm{~mm}$, $\left.\left[\mathrm{Cl}_{2} \mathrm{HCCO}_{2} \mathrm{Et}\right]=500 \mathrm{~mm},[4]=0.50 \mathrm{~mm}\right)$ as a test reaction. ${ }^{[19]}$ The initial rate of the reaction was found to be $1.3( \pm 0.2) \times 10^{-5} \mathrm{M} \mathrm{s}^{-1}$, which is lower than that observed for reactions with the catalyst precursor 2 $\left[2.4( \pm 0.3) \times 10^{-5} \mathrm{M} \mathrm{s}^{-1}\right]$.

The results suggest that Os-catalyzed ATRA reactions of halogenated compounds with styrene can be inhibited by the formation of olefin complexes, in particular when the reactions are performed with high concentrations of styrene. One should point out, however, that we have only indirect evidence for the relevance of styrene complexes under catalytic conditions, and alternative explanations for the observed data cannot be ruled out.

\section{Conclusions}

We have studied the catalytic activity of the Os complex $\left[\mathrm{Cp}^{*} \mathrm{OsBr}_{2}\left(\mathrm{PPh}_{3}\right)\right](2)$ in conjunction with $\mathrm{Mg}$ for intra- and intermolecular atom transfer radical reactions. It was found that the complex is a potent catalyst, which enables the ATRA and ATRC reactions to be performed in an efficient manner. However, under the conditions studied, its activity was either similar or lower than that of $\left[\mathrm{Cp}^{*} \mathrm{RuCl}_{2}\left(\mathrm{PPh}_{3}\right)\right]$ (1). It is thus not justified to use a more expensive and toxic Os complex for these types of reactions. The isolation of $\left[\mathrm{Cp} * \mathrm{OsBr}\left(\mathrm{H}_{2} \mathrm{C}=\mathrm{CHPh}\right)\left(\mathrm{PPh}_{3}\right)\right]$ (4) shows that olefin complexes are more likely to form in reactions with $\mathrm{Cp} * \mathrm{Os}$ catalysts, and this should be considered for future studies with Os-catalyzed polymerization reactions. ${ }^{[7,20]}$

\section{Experimental Section}

General: The complexes $\left[\mathrm{Cp}^{*} \mathrm{RuCl}_{2}\left(\mathrm{PPh}_{3}\right)\right] \quad(\mathbf{1}),{ }^{[21]}[\mathrm{Cp} * \mathrm{RuCl}-$ $\left.\left(\mathrm{PPh}_{3}\right)_{2}\right],{ }^{[22]}$ and $\left[\mathrm{Cp} * \mathrm{OsBr}_{2}\left(\mathrm{PPh}_{3}\right)\right]$ (2), ${ }^{[23]}$ were prepared according to literature procedures. The substrates 1-(2,2,2-trichloroethoxy)-2phenylprop-2-ene, ${ }^{[5 a]} \quad$ 1-(2,2,2-trichloroethoxy)-3-phenylprop-2ene, ${ }^{\text {[24] }} \quad N$-allyl-2,2-dichloro- $N$-phenylacetamide, ${ }^{[25]} \quad N$-allyl-2,2dichloro- $N$-(4-tolylsulfonyl)acetamide, ${ }^{[26]}$ and $\quad N, N$-diallyl-2,2dichloroacetamide ${ }^{[26]}$ for the ATRC reactions were also prepared according to published procedures. $\mathrm{Mg}$ powder ( $>99 \%$ ) was purchased from Fluka and was agitated by means of a stirring bar under dry dinitrogen for $10 \mathrm{~d}$ before use. All ATRA, ATRC, and synthesis reactions were performed in a glove box under dinitrogen. The solvents were collected under dinitrogen from an Innovative Technologies SPS-400-5 solvent system. The commercially available substrates were distilled from appropriate drying agents and stored under dinitrogen. GC measurements were made with a Varian Chrompack CP3-380 apparatus (Chrompack CP-SIL8CB column; $30 \mathrm{~m} ; 250 \mu \mathrm{m})$ coupled to an FID detector. The NMR spectra $\left({ }^{1} \mathrm{H}\right.$, ${ }^{13} \mathrm{C},{ }^{31} \mathrm{P}$ ) were recorded at room temp. with a Bruker AVANCE DPX 400 spectrometer. Chemical shifts are relative to solvent signals as internal references; $\delta\left({ }^{31} \mathrm{P}\right)$ are relative to external $\mathrm{H}_{3} \mathrm{PO}_{4}$ $\left(85 \%\right.$ in $\left.\mathrm{D}_{2} \mathrm{O}\right)$. Microanalyses $(\mathrm{C}, \mathrm{H}, \mathrm{N})$ were performed with an EA 1110 CHN Carlo Erba instrument.

General Procedure for the ATRA Reactions: An aliquot of a stock solution of complex $\mathbf{1}$ or $\mathbf{2}$ in toluene $(400 \mu \mathrm{L}$ of a $1.25 \mathrm{~mm}$ stock solution) was added to a $1.5 \mathrm{~mL}$ vial containing $\mathrm{Mg}$ powder $(100 \mathrm{mg})$. The total volume was increased to $800 \mu \mathrm{L}$ with toluene, and the resulting mixture was stirred at room temp. or $60^{\circ} \mathrm{C}$ for $10 \mathrm{~min}$. The reaction was then initiated by addition of $200 \mu \mathrm{L}$ of a freshly prepared stock solution containing styrene, the chlorinated compound, and mesitylene as an internal standard. The solution was stirred at room temp. or $60^{\circ} \mathrm{C}$, and samples $(25 \mu \mathrm{L})$ were removed at given times from the reaction mixtures, diluted with nondeoxygenated acetone $(500 \mu \mathrm{L})$, and analyzed by GC chromatography.

General Procedure for the ATRC Reactions: An aliquot of a stock solution of complex $\mathbf{1}$ or $\mathbf{2}$ in $\left[\mathrm{D}_{8}\right]$ toluene $(800 \mu \mathrm{L}$ of a $1.25 \mathrm{~mm}$ stock solution) was added to a $1.5 \mathrm{~mL}$ vial that contained $\mathrm{Mg}$ powder $(100 \mathrm{mg})$. The resulting mixture was stirred at $60^{\circ} \mathrm{C}$ for $10 \mathrm{~min}$. The reaction was then initiated by addition of $200 \mu \mathrm{L}$ of a freshly prepared stock solution containing the substrate and mesitylene as an internal standard in $\left[\mathrm{D}_{8}\right]$ toluene. For $N$-allyl-2,2-dichloro- $N$-(4tolylsulfonyl)acetamide, a $1.5 \mathrm{~mL}$ vial was charged with $2.5 \mu \mathrm{mol}$ of the solid catalysts 1 (or 2), $100 \mathrm{mg}$ of $\mathrm{Mg}$, and $800 \mu \mathrm{L}$ of $\left[\mathrm{D}_{8}\right]-$ 
toluene, and the mixture stirred at $60^{\circ} \mathrm{C}$ for $10 \mathrm{~min}$, before $200 \mu \mathrm{L}$ of a freshly prepared stock solution containing the substrate and mesitylene as an internal standard in $\left[\mathrm{D}_{8}\right]$ toluene was added. After $24 \mathrm{~h}$, the reaction mixture was analyzed by ${ }^{1} \mathrm{H}$ NMR spectroscopy.

Reduction of Complexes 1 and 2 with or without Styrene: Complex 1 or $2(5.0 \mu \mathrm{mol})$ and $\mathrm{Mg}$ powder $(100 \mathrm{mg})$ were suspended in $\left[\mathrm{D}_{8}\right]-$ toluene $(1.0 \mathrm{~mL})$. If styrene was used, 200 equiv. ( $1 \mathrm{mmol}$, $114.6 \mu \mathrm{L})$ of it were added. The resulting reaction mixtures were stirred at room temp. for $2 \mathrm{~h}$, and the liquid phase was analyzed by ${ }^{1} \mathrm{H}$ NMR and ${ }^{31} \mathrm{P}$ NMR spectroscopy.

Synthesis of Complex 4: Styrene $(800 \mu \mathrm{L}, 6.99 \mathrm{mmol})$ was added to a suspension of complex 2 (33 mg, $44 \mu \mathrm{mol})$ and $\mathrm{Mg}(300 \mathrm{mg})$ in toluene $(15 \mathrm{~mL})$. The mixture was stirred at $35^{\circ} \mathrm{C}$ for $15 \mathrm{~h}$ and then filtered through a glass frit. Solvents and excess styrene were removed under vacuum to give complex $\mathbf{4}$ as a yellow solid. Yield: $27 \mathrm{mg}$ (ca. $75 \%$ ). ${ }^{1} \mathrm{H}$ NMR (400 MHz, $\left.\mathrm{C}_{6} \mathrm{D}_{6}\right): \delta=1.23$ (d, $J=$ $1.4 \mathrm{~Hz}, 15 \mathrm{H}, \mathrm{C}_{5} \mathrm{Me}_{5}$ ), 2.47 (ddd, $J=15.7, J=7.7, J=2.6 \mathrm{~Hz}, 1$ $\mathrm{H}, \mathrm{CH}=\mathrm{CH}_{2}$ ), 2.91 (ddd, $J=10.2, J=2.8, J=2.6 \mathrm{~Hz}, 1 \mathrm{H}$, $\left.\mathrm{CH}=\mathrm{CH}_{2}\right), 5.71\left(\mathrm{dd}, J=10.2, J=7.7 \mathrm{~Hz}, 1 \mathrm{H}, \mathrm{CH}=\mathrm{CH}_{2}\right), 6.98-$ $8.18\left(\mathrm{~m}, 20 \mathrm{H}\right.$, aromatic) ppm. ${ }^{31} \mathrm{P}\left\{{ }^{1} \mathrm{H}\right\} \mathrm{NMR}\left(162 \mathrm{MHz}, \mathrm{C}_{6} \mathrm{D}_{6}\right)$ : $\delta=7.4$ ppm. ${ }^{13} \mathrm{C}\left\{{ }^{1} \mathrm{H}\right\}$ NMR $\left(101 \mathrm{MHz}, \mathrm{C}_{6} \mathrm{D}_{6}\right): \delta=8.98\left(\mathrm{~s}, \mathrm{C}_{5} M e_{5}\right)$, $21.0\left(\mathrm{~d}, J=4.4 \mathrm{~Hz}, \mathrm{CH}=\mathrm{CH}_{2}\right), 41.8\left(\mathrm{~d}, J=2.9 \mathrm{~Hz}, C \mathrm{H}=\mathrm{CH}_{2}\right)$, $92.1\left(\mathrm{~d}, J=2.9 \mathrm{~Hz}, C_{5} \mathrm{Me}_{5}\right), 124.8-136.9$ (m), 145.9 (s) ppm. Attempts to characterize complex $\mathbf{4}$ by elemental analysis were unfortunately not successful. We assume that the styrene ligand is partially removed during the drying procedure.

Crystallographic Analyses: Single crystals of complex 2 were obtained by slow vapor diffusion of pentane into a benzene solution of 2. Single crystals of complex $\mathbf{3}$ were obtained by slow diffusion of hexane at $-18{ }^{\circ} \mathrm{C}$ into a toluene solution, which was obtained after reduction of complex $\mathbf{2}$ with $\mathrm{Mg}$ and filtration. Intensity data for 2 were collected with an Oxford Diffraction KM-4 CCD dif-

Table 3. Crystallographic data for the complexes 2 and $\mathbf{3 .}$

\begin{tabular}{|c|c|c|}
\hline & Complex 2 & Complex 3 \\
\hline Empirical formula & $\mathrm{C}_{28} \mathrm{H}_{30} \mathrm{Br}_{2} \mathrm{OsP}$ & $\mathrm{C}_{46} \mathrm{H}_{45} \mathrm{BrOsP}_{2}$ \\
\hline$M_{\mathrm{r}}\left[\mathrm{g} \mathrm{mol}^{-1}\right]$ & 747.51 & 929.87 \\
\hline Crystal size $[\mathrm{mm}]$ & $0.32 \times 0.28 \times 0.17$ & $0.31 \times 0.16 \times 0.37$ \\
\hline Crystal system & monoclinic & monoclinic \\
\hline Space Group & $P 2_{1} / n$ & $P 2_{1} / c$ \\
\hline$a[\AA]$ & $8.7145(2)$ & $17.349(2)$ \\
\hline$b[\AA]$ & $32.4584(8)$ & $10.7211(10)$ \\
\hline$c[\AA]$ & $18.2551(6)$ & $20.5972(17)$ \\
\hline$a\left[^{\circ}\right]$ & 90 & 90 \\
\hline$\beta\left[^{\circ}\right]$ & $91.504(3)$ & $101.101(8)$ \\
\hline$\gamma\left[{ }^{\circ}\right]$ & 90 & 90 \\
\hline$V\left[\mathrm{~A}^{3}\right]$ & $5161.8(2)$ & $3759.4(7)$ \\
\hline$Z$ & 8 & 4 \\
\hline$\rho_{\text {calcd. }}\left[\mathrm{g} \mathrm{cm}^{-3}\right]$ & 1.924 & 1.643 \\
\hline$T[K]$ & $140(2)$ & $100(2)$ \\
\hline$\mu\left[\mathrm{mm}^{-1}\right]$ & 8.114 & 4.573 \\
\hline$\theta$ range $\left[{ }^{\circ}\right]$ & $2.64-27.88$ & $3.36-27.51$ \\
\hline Reflections collected & 12237 & 86119 \\
\hline Independent reflections & 12237 & 8624 \\
\hline Absorption corrections & semi-empirical & semi-empirical \\
\hline Max./min. transmissions & $1.00000 / 0.19163$ & $1.0000 / 0.7237$ \\
\hline Data/restraints/parameters & $12237 / 0 / 579$ & $8624 / 0 / 451$ \\
\hline Goodness of fit on $F^{2}$ & 1.125 & 1.242 \\
\hline Final $R$ indices $[I<2 \sigma(I)]$ & $\begin{array}{l}R_{1}=0.0517 \\
w R_{2}=0.1318\end{array}$ & $\begin{array}{l}R_{1}=0.0297 \\
w R_{2}=0.0494\end{array}$ \\
\hline$R$ indices (all data) & $\begin{array}{l}R_{1}=0.0600, \\
w R_{2}=0.1354\end{array}$ & $\begin{array}{l}R_{1}=0.0430 \\
w R_{2}=0.0531\end{array}$ \\
\hline Max. peak/hole $\left[\mathrm{e} \AA^{-3}\right.$ ] & $4.944 /-2.163$ & $0.778 /-0.657$ \\
\hline
\end{tabular}

fractometer, whereas in the case of $\mathbf{3}$ a Bruker APEX II CCD was employed, both having kappa geometry and using graphite-monochromatized Mo- $K_{\alpha}$ radiation $(\lambda=0.71073 \AA)$ at low temperature. A summary of the crystallographic data, the data-collection parameters, and the refinement parameters are given in Table 3. Data reduction was carried out with CrysAlis $\mathrm{PRO}^{[27]}$ (2) and Ev$\operatorname{alCCD}^{[28]}(3)$ and then corrected for absorption. ${ }^{[29]}$ Structure solution and refinement were performed with the SHELXTL software package. ${ }^{[30]}$ The structures were refined by using the full-matrix least-squares routines on $F^{2}$. All non-hydrogen atoms were refined with anisotropic displacement parameters. Hydrogen atoms were included in the models in calculated positions by using the riding model. CCDC-772348 (2) and -772349 (3) contain the supplementary crystallographic data for this paper. These data can be obtained free of charge from The Cambridge Crystallographic Data Centre via www.ccdc.cam.ac.uk/data_request/cif.

\section{Acknowledgments}

This work was supported by the Swiss National Science Foundation and by the Ecole Polytechnique Fédérale de Lausanne (EPFL). We thank Dr. E. Solari for help with the crystallographic measurements.

[1] a) M. S. Kharasch, E. V. Jensen, W. H. Urry, Science 1945, 102, 128 ; b) M. S. Kharasch, W. H. Urry, E. V. Jensen, J. Am. Chem. Soc. 1945, 67, 1626.

[2] a) K. Severin, Curr. Org. Chem. 2006, 10, 217-224; b) R. A. Gossage, L. A. van de Kuil, G. van Koten, Acc. Chem. Res. 1998, 31, 423-431.

[3] a) W. T. Eckenhoff, T. Pintauer, Catal. Rev. 2010, 52, 1-59; b) T. Pintauer, K. Matyjaszewski, Chem. Soc. Rev. 2008, 37, 10871097; c) L. Delaude, A. Demonceau, A. F. Noels, Top. Organomet. Chem. 2004, 11, 155-171; d) H. Nagashima in Ruthenium in Organic Synthesis (Ed.: S.-I. Murahashi), Wiley-VCH, Weinheim, 2004, pp. 333-343; e) A. J. Clark, Chem. Soc. Rev. 2002, 31, 1-11; f) K. I. Kobrakov, A. V. Ivanov, J. Heterocycl. Chem. 2001, 37, 529-539; g) J. Iqbal, B. Bhatia, N. K. Nayyar, Chem. Rev. 1994, 94, 519-564; h) F. Minisci, Acc. Chem. Res. 1975, 8, 165-171.

[4] For selected examples, see: a) J. Muñoz-Molina, T. R. Belderraín, P. J. Pérez, Inorg. Chem. 2010, 49, 642-645; b) M. Pattarozzi, F. Roncaglia, V. Giangiordano, P. Davoli, F. Prati, F. Ghelfi, Synthesis 2010, 694-700; c) T. Pintauer, W. T. Eckenhoff, C. Ricardo, M. N. C. Balili, A. B. Biernesser, S. T. Noonan, M. T. Taylor, Chem. Eur. J. 2009, 15, 38-41; d) C. Ricardo, T. Pintauer, Chem. Commun. 2009, 3029-3031; e) A. J. Clark, P. Wilson, Tetrahedron Lett. 2008, 49, 4848-4850; f) J. M. Muñoz-Molina, T. R. Belderraín, P. J. Pérez, Adv. Synth. Catal. 2008, 350, 2365-2372; g) J. A. Bull, M. G. Hutchings, C. Luján, P. Quayle, Tetrahedron Lett. 2008, 49, 1352-1356; h) W. T. Eckenhoff, S. T. Garrity, T. Pintauer, Eur. J. Inorg. Chem. 2008, 563-571; i) R. N. Ram, N. Kumar, Tetrahedron Lett. 2008, 49, 799-802; j) J. A. Bull, M. G. Hutchings, P. Quayle, Angew. Chem. Int. Ed. 2007, 46, 1869-1872; k) W. T. Eckenhoff, T. Pintauer, Inorg. Chem. 2007, 46, 5844-5846; 1) A. J. Clark, J. V. Geden, S. Thom, P. Wilson, J. Org. Chem. 2007, 72, 59235926; m) J. M. Muñoz-Molina, A. Caballero, M. M. Díaz-Requejo, S. Trofimenko, T. R. Belderraín, P. J. Pérez, Inorg. Chem. 2007, 46, 7725-7730; n) C. V. Stevens, E. Van Meenen, K. G. R. Masschelein, Y. Eeckhout, W. Hooghe, B. D'hondt, V. N. Nemykin, V. V. Zhdankin, Tetrahedron Lett. 2007, 48, 7108-7111; o) D. Yang, Y.-L. Yan, B.-F. Zheng, Q. Gao, N.-Y. Zhu, Org. Lett. 2006, 8, 5757-5760.

[5] For selected examples, see: a) K. Thommes, G. Kiefer, R. Scopelliti, K. Severin, Angew. Chem. Int. Ed. 2009, 48, 8115-8119; b) J. Wolf, K. Thommes, O. Briel, R. Scopelliti, K. Severin, 
Organometallics 2008, 27, 4464-4474; c) R. J. Lundgren, M. A. Rankin, R. McDonald, M. Stradiotto, Organometallics 2008, 27, 254-258; d) B. Dutta, E. Solari, R. Scopelliti, K. Severin, Organometallics 2008, 27, 423-429; e) Y. Borguet, A. Richel, S. Delfosse, A. Leclerc, L. Delaude, A. Demonceau, Tetrahedron Lett. 2007, 48, 6334-6338; f) Y. Motoyama, S. Hanada, K. Shimamoto, H. Nagashima, Tetrahedron 2006, 62, 2779-2788; g) L. Quebatte, E. Solari, R. Scopelliti, K. Severin, Organometallics 2005, 24, 1404-1406; h) Y. Motoyama, S. Hanada, S. Niibayashi, K. Shimamoto, N. Takaoka, H. Nagashima, Tetrahedron 2005, 61, 10216-10226; i) L. Quebatte, M. Haas, E. Solari, R. Scopelliti, Q. T. Nguyen, K. Severin, Angew. Chem. Int. Ed. 2005, 44, 1084-1088; j) L. Quebatte, R. Scopelliti, K. Severin, Eur. J. Inorg. Chem. 2005, 3353-3358; k) L. Quebatte, R. Scopelliti, K. Severin, Angew. Chem. Int. Ed. 2004, 43, 1520-1524; 1) B. T. Lee, T. O. Schrader, B. Martín-Matute, C. R. Kauffman, P. Zhang, M. L. Snapper, Tetrahedron 2004, 60, 73917396; m) O. Tutusaus, S. Delfosse, A. Demonceau, A. F. Noels, C. Viñas, F. Teixidor, Tetrahedron Lett. 2003, 44, 8421-8425; n) O. Tutusaus, C. Viñas, R. Núñez, F. Teixidor, A. Demonceau, S. Delfosse, A. F. Noels, I. Mata, E. Molins, J. Am. Chem. Soc. 2003, 125, 11830-11831; o) B. de Clercq, F. Verpoort, Tetrahedron Lett. 2002, 43, 4687-4690; p) F. Simal, L. Wlodarczak, A. Demonceau, A. F. Noels, Eur. J. Org. Chem. 2001, 14, 2689-2695; q) F. Simal, L. Wlodarczak, A. Demonceau, A. F. Noels, Tetrahedron Lett. 2000, 41, 6071-6074.

[6] a) K. Thommes, B. Içli, R. Scopelliti, K. Severin, Chem. Eur. J. 2007, 13, 6899-6907; b) L. Quebatte, K. Thommes, K. Severin, J. Am. Chem. Soc. 2006, 128, 7440-7441.

[7] a) W. A. Braunecker, W. C. Brown, B. C. Morelli, W. Tang, R. Poli, K. Matyjaszewski, Macromolecules 2007, 40, 8576-8585; b) W. A. Braunecker, Y. Itami, K. Matyjaszewski, Macromolecules 2005, 38, 9402-9404.

[8] M. A. Fernández-Zúmel, K. Thommes, G. Kiefer, A. Sienkiewicz, K. Pierzchala, K. Severin, Chem. Eur. J. 2009, 15, 1160111607.

[9] T. Braun, G. Münch, B. Windmüller, O. Gevert, M. Laubender, H. Werner, Chem. Eur. J. 2003, 9, 2516-2530.

[10] B. Dutta, E. Solari, S. Gauthier, R. Scopelliti, K. Severin, Organometallics 2007, 26, 4791-4799.

[11] P. B. Glaser, T. D. Tilley, Eur. J. Inorg. Chem. 2001, 2747-2750.

[12] C. L. Gross, G. S. Girolami, Organometallics 1996, 15, 53595367.

[13] G. J. Parkins, M. I. Bruce, B. W. Skelton, A. H. White, Inorg. Chim. Acta 2006, 359, 2644-2649.

[14] D. C. Smith Jr., C. M. Haar, L. Luo, C. Li, M. E. Cucullu, C. H. Mahler, S. P. Nolan, Organometallics 1999, 18, 2357 2361 .
[15] C. S. Yi, J. R. Torres-Lubian, N. Liu, A. L. Rheingold, I. A. Guzei, Organometallics 1998, 17, 1257-1259.

[16] For some examples, see: a) J. Vicente, J. Gil-Rubio, J. GuerreroLeal, D. Bautista, Organometallics 2005, 24, 5634; b) E. Lindner, R. M. Jansen, H. A. Mayer, W. Hiller, R. Fawzi, Organometallics 1989, 8, 2355.

[17] For a discussion of the role of olefin complexes in $\mathrm{Cu}$-catalyzed ATRP reactions, see: a) W. A. Braunecker, K. Matyjaszewski, J. Mol. Catal. A 2006, 254, 155-164; b) W. A. Braunecker, N. V. Tsarevsky, T. Pintauer, R. R. Gil, K. Matyjaszewski, Macromolecules 2005, 38, 4081-4088; c) W. A. Braunecker, T. Pintauer, N. V. Tsarevsky, G. Kickelbick, K. Matyjaszewski, J. Organomet. Chem. 2005, 690, 916-924.

[18] The formation of side products can be taken into account by determining the conversion of styrene in addition to the yield of the product. However, it was not possible to calculate the conversion accurately because of the very high styrene/ $\mathrm{Cl}_{3} \mathrm{CCO}_{2} \mathrm{Et}$ ratios used in this study (up to 32:1).

[19] As stated in the Experimental Section, we failed to obtain a satisfactory elemental analysis of complex 4 . The concentration of the catalyst precursor 4 is thus not very precise $( \pm 10 \%)$.

[20] In the case of $\mathrm{Ru}$, an acrylonitrile complex has successfully been used as a catalyst precursor in ATRP reactions: A. SaenzGalindo, H. M. Textle, A. R. Jasso, J. R. Torres-Lubián, J. Polym. Science A 2005, 44, 676-680

[21] T. Arliguie, C. Border, B. Chaudret, J. Devillers, R. Poilblanc, Organometallics 1989, 8, 1308-1314.

[22] Synthesis of $\left[\mathrm{Cp} * \mathrm{RuCl}\left(\mathrm{PPh}_{3}\right)_{2}\right]$ : M. S. Chinn, D. M. Heinekey, J. Am. Chem. Soc. 1990, 112, 5166-5175.

[23] C. L. Gross, G. S. Girolami, Organometallics 2006, 25, 4792 4798.

[24] R. N. Ram, I. Charles, Chem. Commun. 1999, 2267-2268.

[25] T. Sato, Y. Wada, M. Nishimoto, H. Ishibashi, M. Ikeda, J. Chem. Soc. Perkin Trans. 1 1989, 5, 879-886.

[26] H. Nagashima, N. Ozaki, M. Ishii, K. Seki, M. Washiyama, K. Itoh, J. Org. Chem. 1993, 58, 464-470.

[27] Crys Alis PRO, Oxford Diffraction Ltd., Abingdon OX14 1RL, Oxfordshire, UK, 2008.

[28] A. J. M. Duisenberg, L. M. J. Kroon-Batenburg, A. M. M. Schreurs, J. Appl. Crystallogr. 2003, 36, 220-229.

[29] R. H. Blessing, Acta Crystallogr., Sect. A 1995, 51, 33-38.

[30] G. M. Sheldrick, University of Göttingen, Germany, 1997; SHELXTL, version 6.1.4, Bruker AXS Inc., Madison, Wiscon$\sin 53719$, USA, 2003.

Received: April 8, 2010

Published Online: July 2, 2010 